\title{
Economic stagnation in the United States: underlying causes and global consequences
}

ROBERT A. BLECKER*

This paper analyzes the causes of the slow recovery of the US economy since the financial crisis and Great Recession of 2008-9. Fallen house values and excessive household debts continue to depress consumer spending, while corporations are failing to invest in spite of record profits. The increasingly unequal distribution of income limits demand, while long-term structural transformations continue to erode employment creation. An expansionary monetary policy has been incapable of sparking a more robust recovery and fiscal policy has been shifted to an austerity stance. In this context, Brazil and other emerging market nations cannot count on the United States to continue to be the leading source of global demand as it was in previous decades.

Keywords: US economy; economic stagnation; austerity policies; global imbalances; inequality.

JEL Classification: E60; F32; N12; E12.

\section{INTRODUCTION}

This paper was originally presented at a conference focused on how Brazil could double its per capita income in 15 years. The most important determinants of whether Brazil can accelerate its growth sufficiently to achieve such an ambitious goal will undoubtedly be domestic in nature. National policies, institutions, and capabilities are the most important factors in influencing whether a country like Brazil will unleash its economic potential or grow at disappointing rates.

\footnotetext{
* The author is Professor of Economics at American University, Washington, DC 20016, USA. E-mail: blecker@american.edu. He would like to acknowledge helpful comments on earlier versions from Carlos Ibarra, Evan Kraft, Gabe Mathy, and participants in the $10^{\text {th }}$ Economic Forum at the Fundação Getulio Vargas.
} 
Nevertheless, the global economic environment will also be an important factor in either facilitating or constraining the achievement of more rapid growth in Brazil, especially if - as seems likely - exports would be a key component of a new growth strategy. Brazil can do much to boost its own export industries, including by maintaining a competitive exchange rate, investing in new technologies, improving its infrastructure and educational system, and generally enhancing the productivity of those industries. Nevertheless, slow growth in Brazil's major export markets would surely make it more difficult for the country to rely on export expansion as a major ingredient in a strategy for more rapid overall growth, or else would require a reorientation of the country's exports to new and different markets.

This paper will focus on one key player in the global economy, the United States (US). There are, of course, many other key economic players in the world today, including the European Union (EU), China, India, Russia, and various others, as well as Brazil itself. However, the debt-driven growth of the US economy was an important element in driving the overall growth of the global economy in the past few decades, and the inability of the US economy to revive its growth since the financial crisis of 2007-8 and "Great Recession" of 2008-9 will place new constraints on the growth of the entire global economy unless other nations step forward to replace the demand that the US was formerly able to provide.

The reasons why the US is not likely to resume its role as the main driver of global aggregate demand will be elucidated throughout this paper. In brief, the US economy suffers from a number of underlying problems centered on a growing gap between real wages and labor productivity that has contributed to widening inequality, accompanied by long-term changes in the structure and composition of its industries that have broken the formerly strong linkage between output and employment. These problems were temporarily overcome by a debt-financed boom in consumer spending and housing construction during the economic expansion of 2003-7. Since the financial crisis, however, this model of debt-led household expenditures has collapsed. Financially strapped households, faced with depressed asset values (especially for their homes), diminishing employment prospects, and persistent debt burdens, have been unable to resume the rate of expenditures that propelled the US economy prior to the crisis. Business firms, seeing the slow growth of demand for their products, are reluctant to invest in spite of record high profits and low interest rates. And the US government, under pressure from the anti-government "Tea Party" wing of the Republican Party as well as more "moderate" deficit hawks in both political parties, is making matters worse instead of better by imposing fiscal austerity before a robust recovery has taken place.

As a result of all these factors, the US economy is not only experiencing a historically slow recovery from the Great Recession of 2008-9, but is also entering what appears to be a period of slower long-run growth accompanied by heightened inequality in the distribution of income and an inability to generate adequate employment for large parts of the US population. Although the lingering debt problems that lie at the heart of the US slowdown are largely domestic in origin, the constraints that they impose on US spending will reverberate throughout the glob- 
al economy. The global impact of the US economic slowdown will limit the ability of Brazil and other emerging nations to expand their exports in the coming years unless they can create more reciprocal demand for each others' products. Emerging market nations will also need to focus more on the growth of their internal markets, as they will not be able to rely as much as they have on demand derived, directly or indirectly, from highly indebted US households and transmitted to the global economy via trade imbalances.

The rest of this paper is organized as follows. The next section discusses global trade imbalances in relation to three major blocs of countries: net demand generators with trade deficits, manufacturing exporters, and resource exporters (with several countries, including Brazil, having characteristics of the two latter groups). The following section presents evidence showing that the US economy has entered a period of prolonged depression and is not simply suffering from a short-run, cyclical downturn. The fourth section analyzes the underlying causes of the growth slowdown in the US economy, including rising inequality in the distribution of income, the exhaustion of the debt-led model of household expenditures, and longterm structural changes in the composition of US industries. The fifth section considers the monetary and fiscal policies that the US government has pursued since the crisis and evaluates how they have helped or hindered the economic recovery. The concluding section discusses the lessons of the US case for economy theory and the implications of the analysis for the rest of the global economy, especially emerging market nations such as Brazil.

\section{GLOBAL TRADE IMBALANCES AND INTERNATIONAL DEMAND TRANSMISSION}

In the decades preceding the crisis of 2008, global growth was accompanied by certain regular patterns of trade imbalances among major groups of nations (see Blecker, 2002b, 2013). The biggest imbalances consisted in the US deficit and the correspondingly large surpluses of the major East Asian nations, chief among them China and Japan. Within Europe, there was a parallel set of imbalances between the surpluses of the northern European nations (especially Germany) and the deficits of various other nations (especially the UK, Spain, and Greece). In addition, many of the major resource-exporting nations, such as Saudi Arabia and Russia, also had large surpluses. Thus, on the eve of the crisis in 2007, the US had by far the biggest current account deficit, followed distantly by Spain and then the UK, while the three largest surpluses were found in China, Germany, and Japan, followed by several major resource exporters (see Table 1, first column, which shows all countries that had current account imbalances in excess of \pm US\$20 billion as of 2007) ${ }^{1}$.

\footnotetext{
${ }^{1}$ Of course, many other countries have had trade imbalances that are large in proportion to their gross
} 
Table 1: Current account balances,

countries over \pm US\$25 billion, 2007 and 2012

\begin{tabular}{|c|c|c|c|}
\hline \multicolumn{2}{|c|}{2007 (pre-crisis) } & \multicolumn{2}{|c|}{2012 (most recent) } \\
\hline Country & $\begin{array}{l}\text { Current } \\
\text { account } \\
\text { balance }\end{array}$ & Country & $\begin{array}{l}\text { Current } \\
\text { account } \\
\text { balance }\end{array}$ \\
\hline China & 353.2 & Germany & 238.5 \\
\hline Germany & 248.0 & China & 193.1 \\
\hline Japan & 212.1 & Saudi Arabia & 164.7 \\
\hline Saudi Arabia & 93.4 & EU & 154.3 \\
\hline Russia & 71.3 & Kuwait & 79.8 \\
\hline Netherlands & 52.7 & Netherlands & 77.8 \\
\hline Norway & 49.0 & Russia & 74.8 \\
\hline Singapore & 46.3 & Norway & 70.8 \\
\hline Sweden & 43.2 & Switzerland & 70.8 \\
\hline Kuwait & 42.2 & UAE & 66.6 \\
\hline Switzerland & 38.8 & Qatar & 62.3 \\
\hline Taiwan & 35.2 & Japan & 60.4 \\
\hline Iran & 32.6 & Singapore & 51.4 \\
\hline Algeria & 30.6 & Taiwan & 49.9 \\
\hline Libya & 29.8 & Korea & 43.1 \\
\hline Malaysia & 29.7 & Sweden & 31.3 \\
\hline Nigeria & 27.9 & Iran & 27.2 \\
\hline Hong Kong & 25.5 & Libya & 23.9 \\
\hline Korea & 21.8 & Nigeria & 20.4 \\
\hline Romania & -22.9 & South Africa & -24.1 \\
\hline Portugal & -23.4 & Indonesia & -24.1 \\
\hline France & -25.9 & Turkey & -47.8 \\
\hline Poland & -26.5 & Brazil & -54.2 \\
\hline Italy & -27.3 & Australia & -56.9 \\
\hline Turkey & -37.8 & France & -57.1 \\
\hline Greece & -44.7 & Canada & -62.3 \\
\hline Australia & -58.4 & India & -88.2 \\
\hline UK & -62.5 & UK & -93.9 \\
\hline EU & -62.9 & US & -440.4 \\
\hline Spain & -144.3 & & \\
\hline United States & -713.4 & & \\
\hline
\end{tabular}

Source: International Monetary Fund, World Economic Outlook Database, October 2013, http://www.imf.org/external/pubs/tt/weo/2013/02/weodata/index.aspx.

domestic product (GDP), but our focus here is on the imbalances that were large enough to be important factors in international financial flows so we use a cut-off based on the US dollar amounts. 
Since the crisis, the largest of these imbalances have diminished to some extent and the ranking of some countries has changed, but the broad patterns had not changed much as of 2012 (see Table 1, second column). European nations that were forced to adopt harsh austerity policies in response to the eurozone debt crisis, such as Greece, Spain, Italy, and Portugal, no longer have large enough deficits to appear in the table for 2012 because their economies have been severely depressed by those policies; meanwhile, one other major European nation (France) now has a larger deficit. The EU as a whole swung from a deficit of US\$ 62.9 billion in 2007 to a surplus of US\$ 154.3 billion in 2012, mainly as a result of the austerity policies adopted in so many eurozone countries along with Germany's continued large surplus. Meanwhile, a number of countries that have been afflicted with Dutch disease as a result of currency appreciation were experiencing large current account deficits in 2012, including Brazil, Australia, and Canada, while the deficits of a few other emerging market nations (notably India and Turkey) also grew by that year. On the surplus side, Japan's surplus has been reduced by the adoption of stimulus policies under newly reelected Prime Minister Abe as well as by weak global demand for its exports. By 2012, Germany had the largest surplus followed by China, and after them one finds mainly a number of major resource exporters (Saudi Arabia, Kuwait, Netherlands, Russia, Norway, and various other oil producers) along with the EU as a whole, Switzerland, and a few other East Asian nations (Japan, Taiwan, and South Korea).

Abstracting from the details of the individual countries involved, we can broadly characterize these global imbalances as resulting from a triangular pattern of net demand flows among three broad groups of nations: the demand-generating deficit nations (chiefly the US); the nations that mainly export manufactures (such as China, Germany, and Japan); and the resource-exporting countries (such as Saudi Arabia, Russia, and other oil exporters), as shown in Figure 1. The deficit nations have provided net demand for the exports of the manufacturing-based economies, which in turn have created high demand for the exports of the resource-based economies. In addition, many of the deficit nations are also major importers of primary commodities and hence have also created demand directly for the resource exporters. Of course, this diagram is oversimplified, as it ignores the many-sided flows of demand within and between the three blocs of countries shown, but the arrows are intended to illustrate the principal net flows of demand that go, directly or indirectly, from the deficit nations to the two groups of exporting nations.

Of course, not all of the exporters of manufactured goods or primary commodities have large surpluses on current account. Whether they have surpluses or deficits depends on other factors, including their levels of domestic demand, their degrees of trade openness, and their exchange rates. Also, many countries do not fit neatly into only one of the categories shown in Figure 1. Especially, several important countries (including Brazil as well as Canada, Australia, the Netherlands, Norway, and Indonesia) export significant quantities of both primary commodities and manufactured goods. These are precisely the countries whose manufactured exports have been hurt by currency appreciation during the commodity price boom 
Figure 1: Principal Net Flows of Global Aggregate Demand: A Schematic View

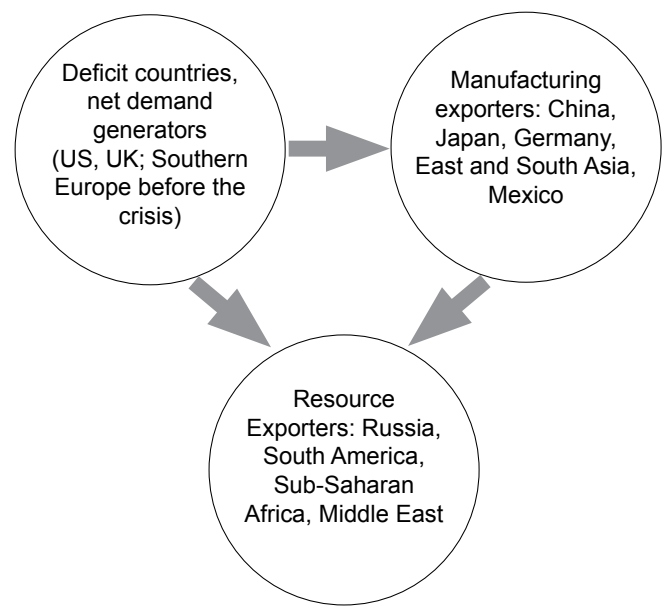

Note: Arrows indicate the direction of net demand flows among the major country groups; the width of the arrows roughly represents the intensity of those demand impulses. Some countries belong in more than one group (for example, Brazil, Malaysia, Canada, Australia, UK, and the Netherlands all export both manufactures and resource-based products). See text for further discussion.

of the past decade. Some of these countries have not experienced the surpluses one might expect based on their resource exports, because these exports are offset by deficits in manufactures brought about by Dutch disease.

It is important to emphasize that the modest reductions in the magnitude of some of the imbalances shown in Table 1 and the rearrangements of which countries rank ahead of each other are not the result of a true global "rebalancing" (see Carvalho, 2013). Rather, these reductions and rearrangements are mainly a result of the depression of global demand that has slowed the growth of world trade since the crisis, combined with the uneven degree to which various countries have adopted either stimulus policies (as in China during the crisis and Japan more recently) or austerity (as in Greece, Spain, the UK, and now the US).

In particular, the reduction in the US external deficit has occurred because US imports have slowed down even more than US exports during the sluggish recovery from the Great Recession. During the business cycle that ran from 2001Q1 to 2007Q4 (peak-to-peak), US real exports of goods and services grew at a $4.6 \%$ annual rate, while US real imports of goods and services grew almost as rapidly at a $4.2 \%$ annual rate. However, from the peak before the Great Recession (2007Q4) to the most recent quarter for which data are available (2013Q2), the growth rate of US real exports slowed down to an annual rate of $2.8 \%$ while the growth rate of US real imports slowed down even more to $0.7 \%^{2}$. US exports did not grow faster during this more recent period, in spite of a low value of the US dollar, because of

\footnotetext{
${ }^{2}$ Author's calculations based on data from the US Bureau of Economic Analysis (BEA), National Income and Product Accounts, Table 1.1.6, data released August 29, 2013, available at www.bea.gov.
} 
depressed conditions in its traditional export markets (especially in Europe), while US imports barely grew at all because of depressed national income at home. Thus, the smaller US current account deficit in 2012 compared with 2007, shown in Table 1 , merely indicates that the US is now transmitting less demand to other regions of the global economy, and not that the US or other countries have made any fundamental adjustments in the conditions that originally led to emergence of chronic global trade imbalances. As a result, global trade imbalances remain an important transmission mechanism for international demand shocks, whether positive (as they were during the US housing bubble of 2003-7) or negative (as they have been since the US recession of 2008-9 and the eurozone crisis more recently).

As the cumulative effect of three decades of chronic US current account deficits, the total net US external debt reached US\$ 4.5 trillion by the end of the second quarter of $2013^{3}$. However, it is unlikely that this net external debt will, in and of itself, be a likely source of a future financial crisis. The US net external debt is more than accounted for by the holdings of US currency and Treasury securities by other countries' central banks ("foreign official assets in the United States"), which totaled US\$ 5.7 trillion at that time. In contrast, the US had a significant net creditor position in foreign direct investment (+ US\$ 2.1 trillion), and a modest net debt position in all other financial assets (- US\$ 1.3 trillion). Central banks in China and many other emerging market nations have accumulated large holdings of US reserve assets, partly in order to limit the appreciation of their currencies and partly as an insurance fund to prevent (or be able to mitigate) future financial crises. These central banks are unlikely to panic and sell off US dollar assets in a short period of time because it would not be in their own self-interest to have their major reserve assets collapse in value. Thus, even though the total US external debt position appears very large, it is unlikely to be the source of a massive sell-off of US assets large enough to spark another financial crisis.

Nevertheless, while it is unlikely that a new crisis will be precipitated by the US net external debt, the internal debt burdens of US households and the difficulties the US is having in recovering from its financial crisis will continue to constrain not only US domestic growth, but also the global level of aggregate demand, for many years to come. Global trade imbalances remain a mechanism for transmitting demand shocks between countries, and under present conditions they are largely transmitting negative rather than positive shocks.

\section{THE LESSER DEPRESSION IN THE US ECONOMY}

Krugman (2011) has aptly dubbed what has been happening in the US economy in recent years as a "Lesser Depression." That is, the situation is certainly

\footnotetext{
${ }^{3}$ Data from US BEA, US. Net International Investment Position, data released September 24, 2013, available at www.bea.gv.
} 
milder than the Great Depression of the 1930s, when unemployment reached $25 \%$ of the labor force. Nevertheless, although what was called the Great Recession of 2008-9 officially ended in July $2009^{4}$, the US economy has never fully recovered from the severe downturn during that recession and remains in a semi-depressed state more than four years later as of this writing (see also Krugman, 2012).

Officially, the US unemployment rate peaked at $10.0 \%$ in October 2009 and fell to $7.3 \%$ by August $2013^{5}$. But this decline in the unemployment rate masks deeper problems in the US labor market. For one thing, the severity of the unemployment is also indicated by its duration: the number of workers who were unemployed for 27 weeks or longer peaked at 6.7 million in April 2010, and remained at a still-high 4.3 million as of August 20136. In addition, the official unemployment statistics only count individuals who are continuing to search for jobs as unemployed. A broader measure of underemployment, which includes discouraged workers (who have given up actively searching but are still interested in working) and those who are working "part-time for economic reasons" (but want full-time positions), registered 13.7\% as of August 2013 - down from its peak of 17.1 during several months of 2009 and 2010, but still historically high for the post-World War II US economy.

Indeed, the official unemployment rate has declined partly because the labor force participation rate has declined significantly. The labor force participation rate (proportion of the population aged 16 years or older who are either employed or unemployed but actively searching for work) fell from a peak of $67.3 \%$ in the first four months of 2000 to a low of $63.2 \%$ in August 2013, which was the lowest rate in more than three decades. Furthermore, the employment-population ratio (also for population aged 16 years or older) dropped precipitously from an average of $63.0 \%$ in the two years just prior to the crisis (2006-7) to an average of $58.5 \%$ from the time when the recovery officially started in July 2009 through August 2013 - and it was virtually flat, with no rising trend, during this latter period. Overall, the level of US employment has been reduced by $4.5 \%$ of the population aged 16 years and older since the Great Recession.

The continued existence of a "jobs crisis" is also illustrated in Figure 2, which shows the total level of nonfarm employment from January 1990 through August 2013. As these data indicate, the jobs crisis was worsened by the Great Recession of 2008-9, but job growth had started to slow down after the previous and milder recession of 2001. Total employment increased sharply during the 1990s, as the number of jobs increased by 22.8 million from 1990 to 2001. In contrast, during

\footnotetext{
${ }^{4}$ All business cycle dates in this paper are taken from the National Bureau of Economic Research (NBER), Business Cycle Dating Committee, "US Business Cycle Expansions and Contractions", http:// www.nber.org/cycles.html.

${ }^{5}$ Data from US Bureau of Labor Statistics (BLS), Labor Force Statistics from the Current Population Survey, downloaded September 8, 2013, www.bls.gov.

${ }^{6}$ Data from BLS, Labor Force Statistics from the Current Population Survey, downloaded November 14, 2013, www.bls.gov.
} 
the entire period from 2001 to 2013 , total employment increased by only 3.5 million, which is a paltry number of jobs at a time when the civilian, noninstitutional population aged 16 and over rose by about 31 million. Clearly, the US economy is not providing enough jobs for its population.

Figure 2: Total US nonfarm employment in millions, monthly, January 1990 to August 2013

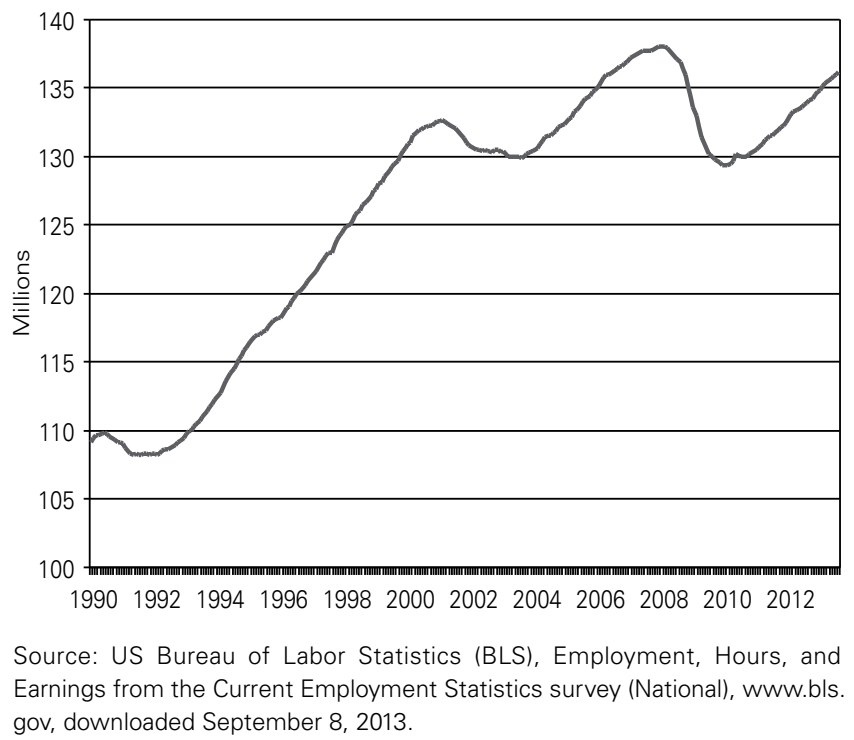

In cyclical terms, Figure 2 also demonstrates the unusual nature of the US "recovery" since 2009. That is, as of August 2013 - more than four years after the recession officially ended in July 2009 - the total number of jobs had not yet returned to its previous peak level, but instead remained about 2 million lower than it was at the end of 2007. Such a long period without employment recovering to its pre-recession peak has not occurred in the US economy since the 1930s. From the late 1940s through the 1980s, US employment typically exhibited a V-shaped pattern during a recession and recovery, with a quick decline followed by an equally rapid rebound, and the previous peak level was usually achieved within two years or less after the recession began. Since the 1990s, however, employment has rather exhibited more of a U-shaped pattern during recessions and recoveries, with a gradual decline followed by a slow and protracted increase - which has more and more prolonged in every business cycle since the recession of 1990-17. Following the 2001

\footnotetext{
${ }^{7}$ For a graphical representation of the contrast between the V- and U-shaped patterns of US employment during post-war business cycles, see the chart, "US recent recession and recovery compared with earlier cycles" at http://www.calculatedriskblog.com/2013/05/when-will-payroll-employment-exceed-pre.html. Olney and Pacitti (2013) argue that the shift from a V-shape to a U-shape and the increasingly protracted
} 
recession, it took nearly four years for employment to return to its previous peak level, as shown in Figure 2. But after the 2008-9 recession, employment had not yet returned to its previous peak level almost six years after the recession started.

Table 2: Average annual GDP growth rates, in percent, last four US recoveries (first 16 quarters after trough of recession)

\begin{tabular}{cc}
\hline Four years (16 quarters) starting in & Average annual growth rate (\%) \\
\hline 198301 & 5.2 \\
199102 & 3.3 \\
200201 & 3.1 \\
200903 & 2.2 \\
\hline
\end{tabular}

Source: Author's calculations from US BEA, National Income and Product Accounts (NIPA), Table 1.1.1, data released August 29, 2013, www.bea.gov.

The proximate cause of the slow recovery of employment is not hard to find: it is the slow growth of output (gross domestic product, or GDP) over the past several years, compared with other recent business cycle recoveries. Table 2 shows that GDP grew at an average annual rate of $2.2 \%$ for the four-year (16-quarter) period from 2009Q3 through 2013Q2, which was notably less than in the first four years of the previous three recoveries since the early 1980s. In fact, the pace of the recovery has been slower with each successive business cycle since that time. Because labor productivity grew at an average annual rate of $1.5 \%$ between 2009Q3 and 2013Q2, the output (GDP) growth rate of only 2.2\% during that same period naturally resulted in only anemic employment growth of about $0.7 \%$ per year. The deeper causes of this slow growth of employment will be explored in the following two sections.

\section{UNDERLYING CAUSES}

\section{Increasing inequality in the distribution of income}

The most fundamental, underlying cause of the growth slowdown in the US economy is the squeeze on middle-class and working-class incomes that has resulted from the fact that real labor compensation has growth more slowly than labor productivity over the past three decades (see Mishel, 2012). Although the trend toward a widening gap between labor compensation and labor productivity dates back to the late 1970s, this gap has widened significantly in recent years (see Figure 3). Real compensation per hour was essentially flat from 2003 to 2013, while labor productivity (output per hour) continued to rise - and if anything the latter accelerated after the recovery from the 2008-9 recession. As a result of this widening

recovery of employment following recent recessions can be attributed to the rising share of services in total employment. For further discussion of these issues, see below. 
gap, the labor share of value added (in the nonfinancial corporate business sector) has fallen to a historically low level since 2000 , after oscillating around a roughly constant trend for the previous four decades (see Figure 4; note that this chart shows an index of the labor share based on 100 in 1960-2, rather than the share itself).

Figure 3. Labor productivity (output per hour) and real hourly compensation, US nonfinancial corporate business sector, quarterly, 196001-201302

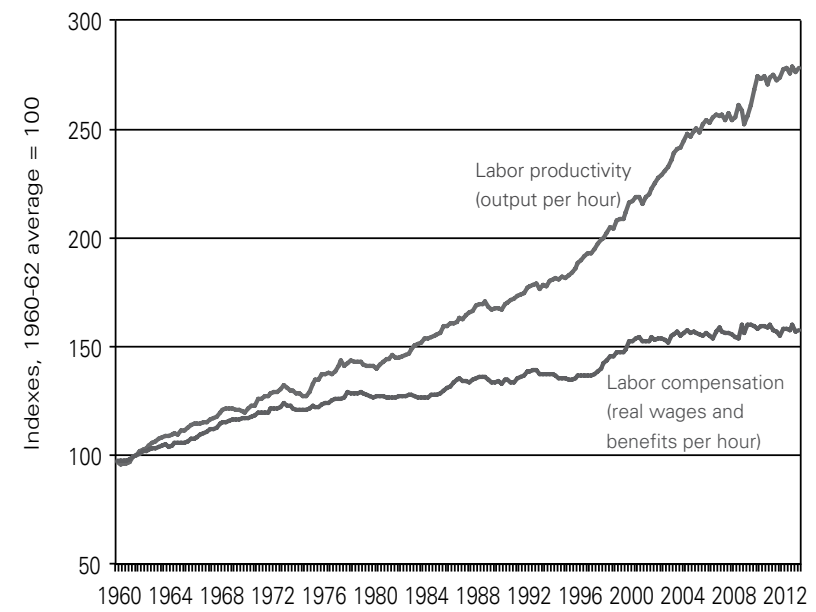

Source: BLS, Major Sector Productivity and Costs, downloaded September 12, 2013, www.bls.gov, and author's calculations.

Figure 4. Index of the labor share of value added, 1960-62 average $=100$, US nonfinancial corporate business sector, quarterly 196001 to 201302

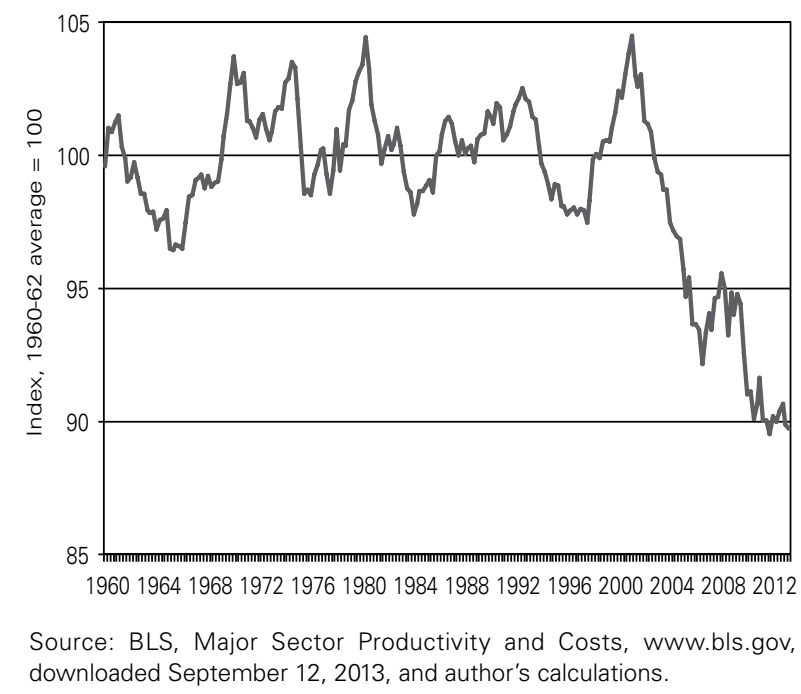


The falling share of wages in US national income has been accompanied by a stunning concentration of household income in the hands of the wealthiest strata of the US population (see Figure 5). Not only has the share of income received by the top $1 \%$ of households increased dramatically in recent years, but within that the top $0.01 \%$ (that is, the richest $1 \%$ of the richest $1 \%$ ) has also increased its share notably. As of the most recent year for which data are available (2012), the wealthiest $1 \%$ received more than $20 \%$ of total income, while the richest $0.01 \%$ obtained over $5 \%$. In other words, one out of every 10,000 Americans was receiving US\$ 1 out of every US\$20 of income. These measures of income concentration have exhibited an increasing trend since the early 1980s, and have brought the distribution of household income back to a level of inequality not seen in the US since the late 1920s, on the eve of the stock market crash of 1929 and Great Depression of the 1930s. ${ }^{8}$ Moreover, Saez (2013) also finds that $95 \%$ of the income gains during the US recovery (that is, from 2009 through 2012) were captured by the top $1 \%$.

Figure 5. The income shares of the top 1\% ( $\mathbf{\square}$, left scale) and top $0.01 \%$

(घ, right scale) in the US, including capital gains, annually, 1913-2012

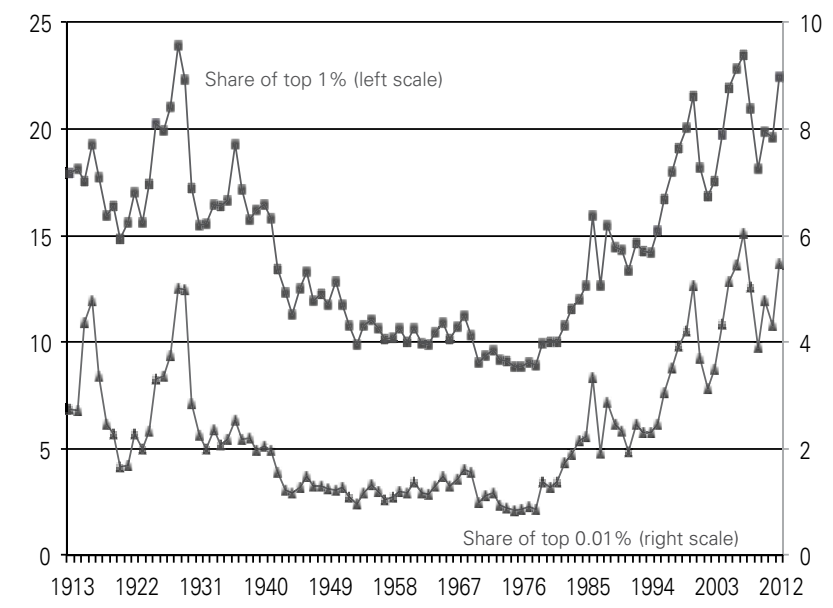

Source: Saez (2013), and spreadsheet made available by the author at http:// elsa.berkeley.edu/ saez/TabFig2012prel.xls, Table A3. Note data for 2012 are preliminary.

A falling labor share and rising inequality put downward pressure on aggregate demand for a simple reason: most of GDP consists in consumption expenditures, and workers and middle-income households tend to spend a much higher share of their income on consumption (and to save a correspondingly lower share) com-

\footnotetext{
${ }^{8}$ Saez (2013) shows that this increasing concentration of income results partly from rising capital gains for wealthy asset holders, but is also observed in other income. The data shown in Figure 5 are for total income including capital gains. For additional perspectives on increasing inequality in the US, see Mishel et al. (2012).
} 
pared with recipients of capital income and the very wealthy. Of course, this wellknown negative effect of greater inequality on consumption can possibly be outweighed by positive effects of greater inequality on investment, if higher profits induce firms to investment at higher rates (Marglin \& Bhaduri, 1990). Furthermore, reductions in labor costs can possibly make a country's tradable goods and services more competitive, thereby leading to increased net exports (Blecker, 1989). Thus, in theory, the potential impact of a lower labor share and increased inequality on overall GDP (measured as the sum of private consumption and investment, government purchases, and net exports) is ambiguous (see Blecker, 2002a, 2011).

Nevertheless, most recent empirical evidence indicates that the potentially positive effects of lower labor costs, higher profit margins, and increased inequality on investment and net exports, if they exist at all, are not strong enough to outweigh the depressing impact of these trends on consumption, which is by far the largest component of US GDP 9 . In the 2012 US presidential election, Republican candidate Mitt Romney used the image of wealthy people as "job creators" to argue for why they should receive lower tax rates: supposedly if the wealthy have higher after-tax income, this would encourage them to invest more and create more employment. However, the evidence we have reviewed so far suggests exactly the opposite: that as income has become more concentrated in the hands of the richest Americans and the share of labor has decreased, and while the wealthy have also benefited from various tax cuts (not only in terms of marginal tax rates, but also in the form of preferential rates for capital gains and long-term dividend income), employment generation has decelerated tremendously.

\section{The housing bubble and household debt}

The US economy did experience rapid growth during the "new economy" boom of the late 1990s and somewhat more modest growth during the housing bubble in the period 2003-7. How was it possible for the economy to grow, when wages were squeezed and the overall distribution of income was becoming more concentrated? For the late 1990s, the growth was enabled in part because wages (labor compensation per hour) did rise briefly between about 1996 and 2000. This was the only period of significantly increased real labor compensation during the past two decades (see Figure 3), and the rise in compensation in those years can be attributed to the strong growth in employment at the time (Figure 2). But more importantly, the last two periods of economic expansion in the US - and especially the more recent one (2003-7) — were facilitated by an enormous wave of

\footnotetext{
${ }^{9}$ The ratio of consumption to GDP in the US averaged slightly over $2 / 3$ (67.6\% to be exact) between 2000Q1 and 2013Q2, according to author's calculations based on data from US BEA, National Income and Product Accounts, Table 1.1.5, data released August 29, 2013, www.bea.gov. For empirical research showing that the US economy is generally wage-led, see Onaran et al. (2011) and earlier studies referenced therein and also surveyed by Blecker (2011). For a contrary earlier study, see Barbosa Filho and Taylor (2006).
} 
borrowing by US households that enabled many middle-class and working-class families to consume more than they could afford based on their largely stagnant real earnings (see, among others, Pollin, 2003; Palley, 2013; Setterfield, 2103; Wisman, 2013).

As Figure 6 shows, most of the increase in household debt (measured as a percentage of disposable personal income) consisted in residential mortgages (housing loans). As is well known, a deregulated banking system in the early 2000s lowered its lending standards and began to make large loans to families who often could not afford the mortgages they were taking out, while offloading the risk onto other financial institutions and unsuspecting portfolio investors via securitization of the mortgages (see, e.g., Shiller, 2008). The most egregious case of this was the infamous "subprime" mortgages, in which borrowers did not have to meet normal prudential standards for being creditworthy. This lending boom fed into the bubble in house prices, which began to rise rapidly in real terms in the late 1990s and then accelerated until they peaked in 2006 and later collapsed in the financial crisis (see Figure 7). The excessive lending and price bubble in the housing sector mutually reinforced each other, as mortgages were extended based on expectations of continued large increases in house prices while the price increases in turn were driven by the high volume of house purchases facilitated by the unrestrained lending.

Figure 6: US household debt (consumer + mortgage) as percentages of disposable personal income, 196001 to 201301

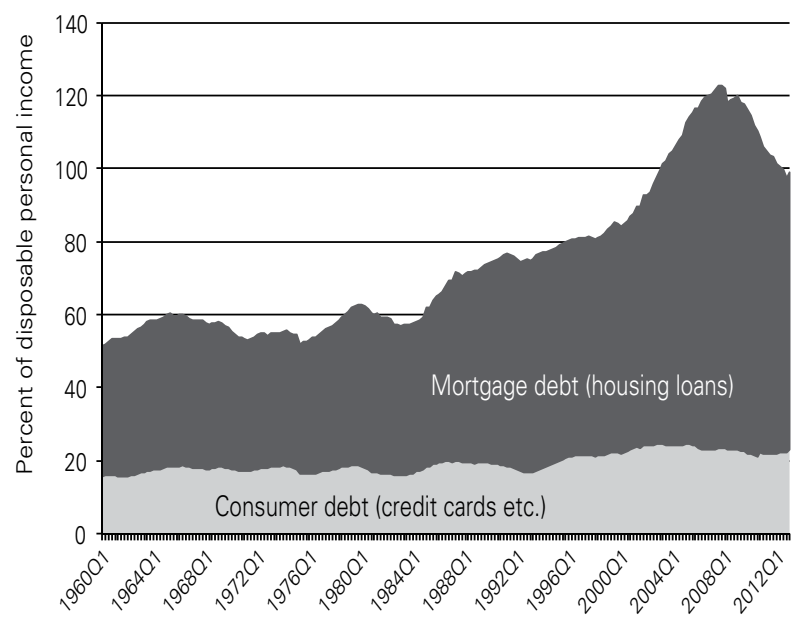

Source: Author's calculations based on data from: Federal Reserve, Z.1 Statistical Release for June 6, 2013, http://www.federalreserve.gov/econresdata/statisticsdata.htm; and BEA, NIPA Table 2.1, data released August 29, 2013, www.bea.gov. 
Figure 7: US real house price index, quarterly, 199101 to 201302 (seasonally adjusted)

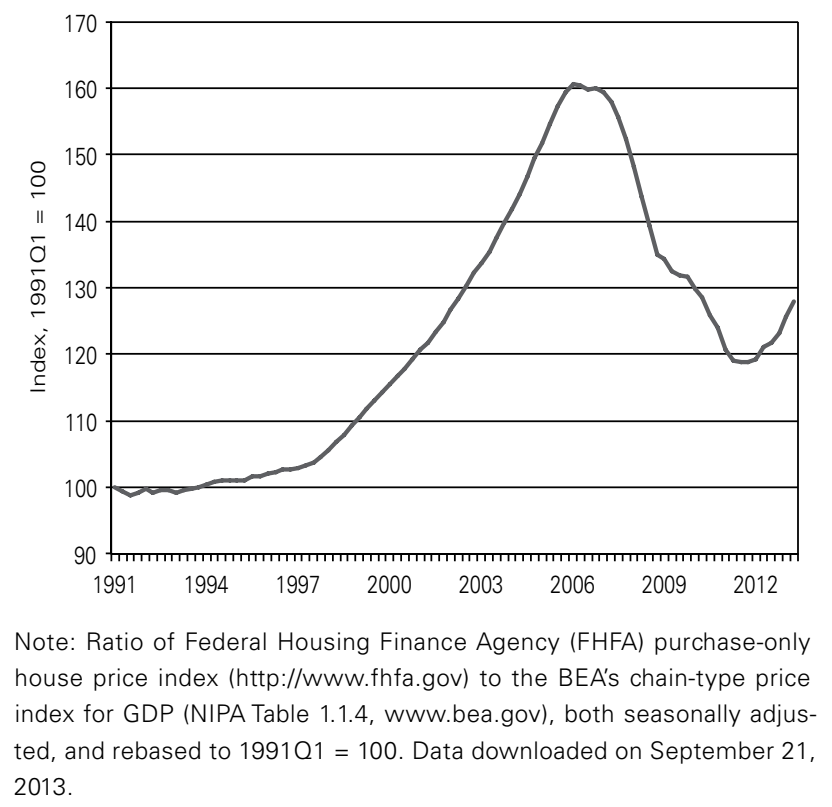

Although the type of debt that increased the most was residential mortgages, the ability of households to borrow more via mortgage debt also enabled them to spend large amounts (relative to their income) on consumer goods and services (see Cynamon \& Fazzari, 2013b). On the one hand, being able to borrow large amounts (often with little or no down payment) for a house freed up current income to spend on consumption. On the other hand, some of the mortgage debt consisted of "home equity loans" that use the borrower's home as collateral but can be spent on any type of consumer goods or services. Other consumer debt rose more modestly during the late 1990s and early 2000s, but the US tax system offers considerable advantages for borrowing via mortgages and home equity loans by making the interest payments on these loans deductible for income tax purposes. As a result, households - encouraged by deregulated and irresponsible lenders - chose to take out more of these types of loans while increasing their overall spending relative to income, until the crash of the housing bubble in 2007.

As house prices leveled off and then began to fall (see Figure 7), while adjustable interest rates on many mortgages were reset upward, more and more households became unable to service their debts (and could only sell their houses at a loss, or for less than they had borrowed, if they could sell at all). By 2007-8, increasing numbers of families became delinquent in their mortgage payments, and more and more households eventually defaulted on their mortgages over the next sev- 
eral years ${ }^{10}$. As investors realized that the securitized mortgages included many nonperforming loans, the securitized mortgage-based assets collapsed in value, thus precipitating the financial crisis of 2007-8. The story of how the collapse in US mortgage-backed securities fed through the financial system both within the US and across many other parts of the world is well-known, and will not be repeated here (see, for example, Roubini \& Mihm, 2011). What is relevant here is that the collapse in housing values, tightening of lending standards, and reduction in household borrowing that resulted from the 2007-8 financial crisis combined to end even the modest spurt of debt-led growth that the US economy had experienced in the 2003-7 period. Since the economy entered a recession in 2008-9 and, as we have seen, employment fell dramatically while lending was reduced, households have been unable to resume the pace of consumption expenditures and housing purchases that they were previously able to achieve.

With many workers either unemployed, out of the labor force, or fearing job losses, and with families needing to repair their balance sheets by paying down debts (so-called "deleveraging"), house purchases and housing construction have been severely depressed for the last several years. One key indicator is the number of new housing units started each month, which has averaged only about 57,000 per month since the end of the recession in July 2009 after averaging about 152,000 from $2003-7^{11}$ - and this is in spite of the fact that interest rates have been at their lowest level in many decades since late 2008 (as discussed below). Another measure of housing construction is real investment spending on residential structures in the GDP accounts, which as of 2013Q2 still remained $45 \%$ below its peak level in 2005Q3.

\section{Business investment and corporate profits}

The drop-off in household spending on consumption and housing could be offset, of course, if businesses were to pick up the pace of investment in plant and equipment (including, in the new definition of investment currently used in the US GDP accounts, "information property products" such as computer software). Two factors that are normally believed to drive business investment - corporate profits and interest rates - have both been at very favorable levels since the post-2009 recovery began. Interest rates have been reduced to historically low levels by Federal Reserve policy, as will be discussed in more depth. Meanwhile, corporate profits have soared to record-breaking levels in real terms in the past few years (see Figure

\footnotetext{
${ }^{10}$ See Federal Reserve Bank of St. Louis, FRED database, Delinquency Rate On Single-Family Residential Mortgages, Booked In Domestic Offices, All Commercial Banks (DRSFRMACBS), http://research. stlouisfed.org/fred2/series/DRSFRMACBS? cid $=32440$.

${ }^{11}$ Author's calculations based on data from US Census Bureau, New Residential Construction, Housing Units Started: United States, not seasonally adjusted, total units, downloaded September 12, 2013 from www.census.gov.
} 
8). In addition, with the US dollar having depreciated compared to most other international currencies over the past decade, the US has again become a more attractive location for investment by multinational companies (whether American or of other nationalities).

Figure 8: Real gross profits of nonfinancial corporations and gross nonresidential fixed investment, US, quarterly data at annual rates in billions of 2009 chained dollars, 200001-201302

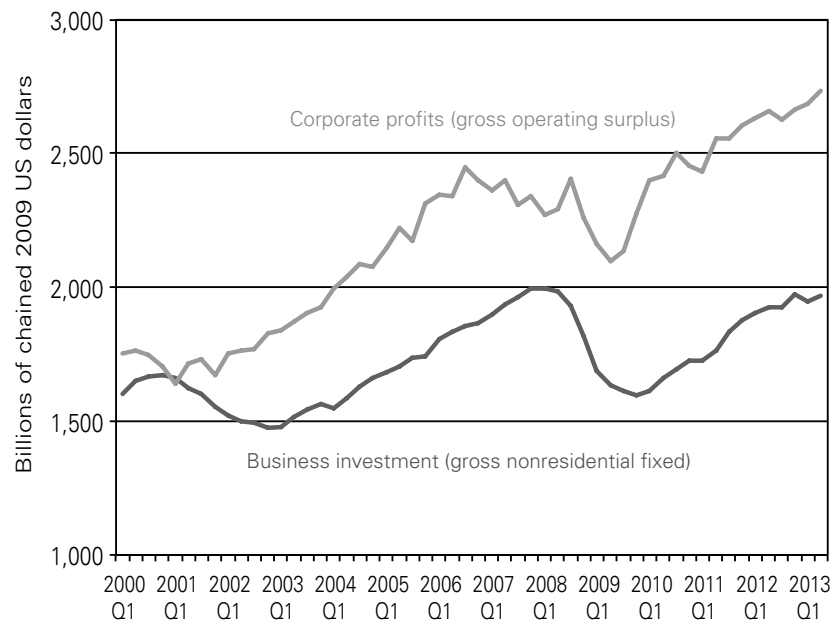

Source: BEA, NNIPA Tables 1.1.6 and 1.14, data released August 29, 2013, www.bea.gov, and author's calculations.

Yet, as Figure 8 also shows, in the most recent quarter for which data is available at the time of this writing (2013Q2), real business fixed investment was still slightly below its previous peak level of 2008Q2, even though real corporate profits already exceeded their previous peak level (from 2006Q3) by $12 \%{ }^{12}$. These aggregate data do mask important differences between investment in different types of capital goods: in particular, investment in equipment and intellectual property products has grown somewhat above previous peak levels during the recovery, while investment in nonresidential structures (that is, business construction, for example of factories, office buildings, or shopping centers) remains depressed. Nevertheless, overall US business investment has remained relatively flat four years into the recovery, in spite of the fact that corporate profits are up, interest rates are low, and the dollar is down.

The explanation for this shortfall in investment lies in the most fundamental

\footnotetext{
${ }^{12}$ Thus, business investment peaked two quarters after the official peak of the previous cycle in 2007Q4, while corporate profits peaked more than a year before the official start of the recession and hence can be regarded as a leading indicator. Although it is normal for profits to peak somewhat before a recession begins, the fact that business investment peaked so late in this recession was a result of the fact that the recession began with a collapse of residential investment due to the bursting of the housing bubble.
} 
theory that explains business investment: the accelerator principle, developed by Samuelson (1939) among others. Very simply, business firms desire to expand their capital stocks when their output is growing (or expected to grow), so the flow of investment (which, after adjusting for the depreciation of existing capital, equals the change in the capital stock) depends primarily on the rate of growth of output or sales. This principle can be modified in many ways, for example by taking account of the cost of capital (which depends on interest rates, prices of capital goods, and tax policies) and potential financial or "liquidity" constraints (which can be relieved by the internal funds or cash flow of corporations) ${ }^{13}$. But no matter how low is the cost of capital or how high are corporate earnings, if the markets for firms' products are not expanding, firms will not find it worthwhile to invest in new capital goods that would expand their productive capacity.

Thus, the US economy is presently trapped in a vicious cycle of the old-fashioned "multiplier-accelerator" variety, in which slow growth of output induces a low rate of investment, the low rate of investment in turn provides little stimulus to income and employment, and the resulting slow growth of output and sales continues to keep investment depressed. The consequences of this low investment rate are not limited to the short run, however. Reifschneider et al. (2013) find that the trend of potential output has decelerated since the financial crisis and ensuing recession, and according to their estimates "a reduction in capital deepening — which we view as mostly an endogenous response to weak demand - caused almost half of the cumulative shortfall in potential output from its pre-crisis trend" (p. 33).

\section{Long-term structural changes}

A more unequal distribution of income, the bursting of the housing bubble, continued consumer debt burdens, and sluggish business investment can all be blamed for the slow recovery of the US economy from the 2008-9 recession and the disappointing growth trends since the beginning of the 2000s. Fiscal austerity has also played a role in delaying the recovery, as will be discussed in the following section. However, these demand-side factors cannot fully account for the growing disjuncture between output growth and employment generation that has emerged in recent years. As of August 2013, US employment was still about $1.4 \%$ below its previous cyclical peak in late 2007 and early 2008 (see Figure 2), even though real GDP was $4.6 \%$ higher in 2013Q2 compared with its previous peak in 2007Q4. If even the meager growth that has occurred is not generating many jobs, there must be other factors at work.

The structural transformations in the US economy over the past half century

\footnotetext{
${ }^{13}$ See Chirinko et al. (1999) for econometric estimates of a standard investment function for the US economy and Chirinko (1993) for a comprehensive survey of earlier empirical estimates on this topic. The theory of financially constrained investment can be found in Stiglitz and Weiss (1981) and Minksy (1986), among others.
} 
have been dominated by two major (and related) trends. First, there has been a notable shift in the composition of GDP and employment from manufacturing to services, and within the latter a rising proportion especially of financial services (defined as finance, insurance, and real estate, or the so-called "FIRE" sectors). Second, there has been a significant offshoring of major parts of US industrial production, especially the more labor-intensive operations, resulting in huge losses of manufacturing jobs, chronic trade deficits in manufactured goods, and a manufacturing sector in which the remaining activities are heavily integrated into global supply chains ${ }^{14}$.

Aside from the fact that the share of services has increased, Basu and Foley (2013) observe that some of the most rapidly growing service sectors in the US economy do not have what they call "measurable value added" (MVA). Because there are no independent measures of output and inputs for these sectors, their value added is imputed in the GDP accounts based on the amount of income they generate. In fact, the share of US GDP consisting of goods (including agricultural and other goods as well as manufacturing and construction) and services that do have MVA (for example, wholesale and retain trade, transportation, information, arts and entertainment, and tourism and accommodation) has fallen secularly over time, while the share of services without MVA (including education, health, and government as well as FIRE) has increased (the shift amounts to 17 percentage points of GDP cumulatively between 1960 and 2012 $)^{15}$.

The problems generated by these transformations for the output-employment link are two-fold. On the one hand, the imputed output of the service sectors that lack MVA can be a poor indicator of employment needs in those activities, especially in FIRE where the increased profits of financial companies and their top employees may be unmatched by any gains in actual employment. Thus, as the proportion of these activities in reported GDP rises, the link between total GDP and employment is weakened. On the other hand, in the remaining manufacturing activities and other sectors (either goods or services production) that do generate MVA, labor requirements have been diminished by a combination of automation and outsourcing - and the latter in turn is greatly facilitated by technological changes in global transportation and communications as well as by trade liberalization.

Olney and Pacitti (2013) argue that the changing composition of the US economy has affected the cyclical behavior of employment as well as its longer-term trends. They note that employment has tended to decline and recover much more gradually in business cycle downturns since the early 1990s, as discussed earlier (see the discussion of U-shaped vs. V-shaped patterns in business cycles in third section, above). Olney and Pacitti attribute this shift to the rising share of services, because service producers do not need to hire back laid-off workers quickly in a

\footnotetext{
${ }^{14}$ Milberg and Winkler (2013) examine the economics of outsourcing and global value chains.

${ }^{15}$ Author's calculations based on data in BEA, "Value Added by Industry as a Percentage of Gross Domestic Product," data released April 25, 2013, downloaded from www.bea.gov.
} 
recovery in order to restock inventories in advance of rising demand (as manufacturing industries must). Thus, service producers wait until after demand actually grows before hiring more workers, and hence the positive feedbacks between rising employment and revived demand in a recovery period are attenuated in a servicedominated economy.

Figure 9: Indexes of output and employment for the US manufacturing sector, based on $2000=100$, quarterly, 200001 to 201302

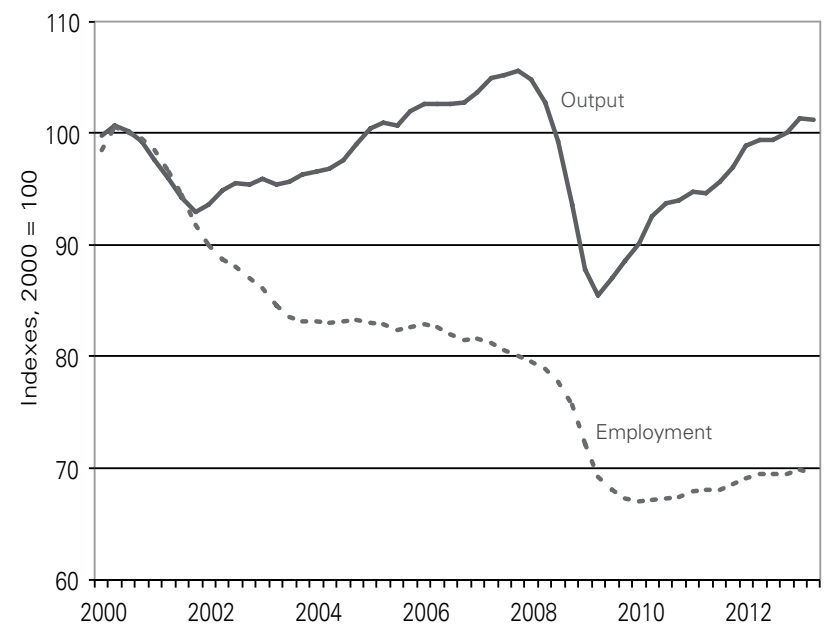

Source: BLS, Productivity and Costs, www.bls.gov; and author's calculations.

Although the increasing share of services in US production can account for the changing behavior of total employment, it should be noted that the delinking of output and employment trends is also found within what remains of the US manufacturing sector. As Figure 9 shows, US manufacturing employment has declined significantly since 2000, even though manufacturing output (value added) has a roughly constant trend (apart from cyclical ups and downs). Manufacturing employment never recovered after the recession of 2001 - at which time the US economy also faced a rising tide of Chinese imports after China joined the World Trade Organization (WTO) and was granted most-favorednation trade status in the US - even though output (measured by value added) started recovering in 2002. Since the trough of the Great Recession in 2009, manufacturing employment has only barely ticked upward, and as of 2013Q2 remained $30 \%$ below its level in 2000 .

Of course, US manufacturing output (measured by real value added) has not grown very much during these years (in the first half of 2013 it was barely back to its level from 2000), but the combined effect of accelerated technological change (and hence rapid productivity growth) and increased outsourcing (and hence slower growth of domestic value added) on manufacturing employment in the US has 
simply been devastating ${ }^{16}$. There has been much talk of a revival of US manufacturing in recent years, and there is some truth to this in the sense that output has experienced a cyclical recovery and certain industries (for example, automobiles) are performing relatively better than in the recent past, but the data simply do not show a significant revival of employment in the US manufacturing sector ${ }^{17}$.

\section{POLICY RESPONSES}

The outbreak of the financial crisis in 2007-8 and the severity of the recession in 2008-9 led to various policy responses by the fiscal and monetary authorities in the US. Overall, the monetary responses of the Federal Reserve were more timely and appropriate in both magnitude and direction, while the fiscal responses of the President and Congress - largely for political reasons - were often too little, too late, and too short, and eventually went in the wrong direction. By 2011, fiscal policy had swung from a mildly expansionary mode into an austerity stance, which began to hinder rather than help the already slow and delayed recovery. Unfortunately, this divergence between the monetary and fiscal policy responses has occurred in a situation in which, in principle, fiscal policy is by far the more powerful type of stimulus, and monetary policy has reached the limits of its potential effectiveness. The rest of this section will outline the monetary and fiscal policy measures adopted and assess their impact on the current recovery and the longerterm prospects for the US economy.

\section{Monetary policy}

Fed Chairman Ben Bernanke was initially slow to recognize how deep and wide would be the impact of the bursting of the housing bubble, but once the magnitude of the financial crisis became clear he led the Fed into dramatic and unprecedented efforts to mitigate that crisis and prevent the ensuing recession from turning into another Great Depression (see, for example, Roubini and Mihm, 2012).

\footnotetext{
${ }^{16}$ The McKinsey Global Institute (2012), although generally offering an optimistic perspective on trends in global manufacturing, does acknowledge that "Manufacturing cannot be expected to create mass employment in advanced economies on the scale that it did decades ago" (p. 4). See Scott (2012) and Autor et al. (2013) for estimates of job and wage losses attributable to increased US imports from China alone. For a broader estimate of the net impact of the nonoil trade deficit on US employment, see Scott (2008).

${ }^{17}$ An example of such talk is found in a speech by Barack Obama (2013) in which he made the following claim: "After a decade in which many jobs left the United States to go overseas, now we're seeing companies starting to bring jobs back because they're seeing the advantages of being located here. Caterpillar is bringing jobs back from Japan. Ford is bringing jobs back from Mexico. After locating plants in other countries like China, Intel is opening its most advanced plant right here in the United States." Although some of these individual examples may be true (one qualification is that Ford is expanding jobs in Mexico as well as in the US, not bringing jobs from the former to the latter), the data in Figure 9 show that these cases do not yet add up to a significant rise in overall US manufacturing employment.
} 
Until mid-2007, Bernanke (and other Fed leaders) tended to assert that the impact of the housing bubble collapse could be contained within the housing sector itself. But by late 2007, and especially after the failures of Bear Stearns, AIG, and Lehman Brothers in 2008, he and other Fed officials realized how broadly and deeply the housing crisis would affect the entire financial system, including commercial banks, investment firms, derivative markets, insurance companies, equity markets, and other institutions, both domestically and internationally.

As early as August 2007, when house prices and the stock market were already falling, the Fed began to cut its interest rate target (the so-called "federal funds rate," which is the rate on overnight interbank loans of reserves) in a series of gradual steps. The Fed accelerated its interest rate reductions after the collapse of Bear Stearns in March 2008, and then cut its target rate even more abruptly to nearly zero following the failure of Lehman Brothers in September 2008. As shown in Figure 10, short-term rates on US Treasury Bills (T-Bills) followed the Fed's target very closely. Thus, policy rates and short-term rates have effectively been at or close to the "zero lower bound" (ZLB) since the end of 2008. In effect, conventional monetary policy is caught in what Keynes (1936) called a "liquidity trap," in which expansionary monetary policies can no longer be used to push interest rates any lower ${ }^{18}$.

Figure 10: Selected US interest rates, monthly, January 2005 to September 2013

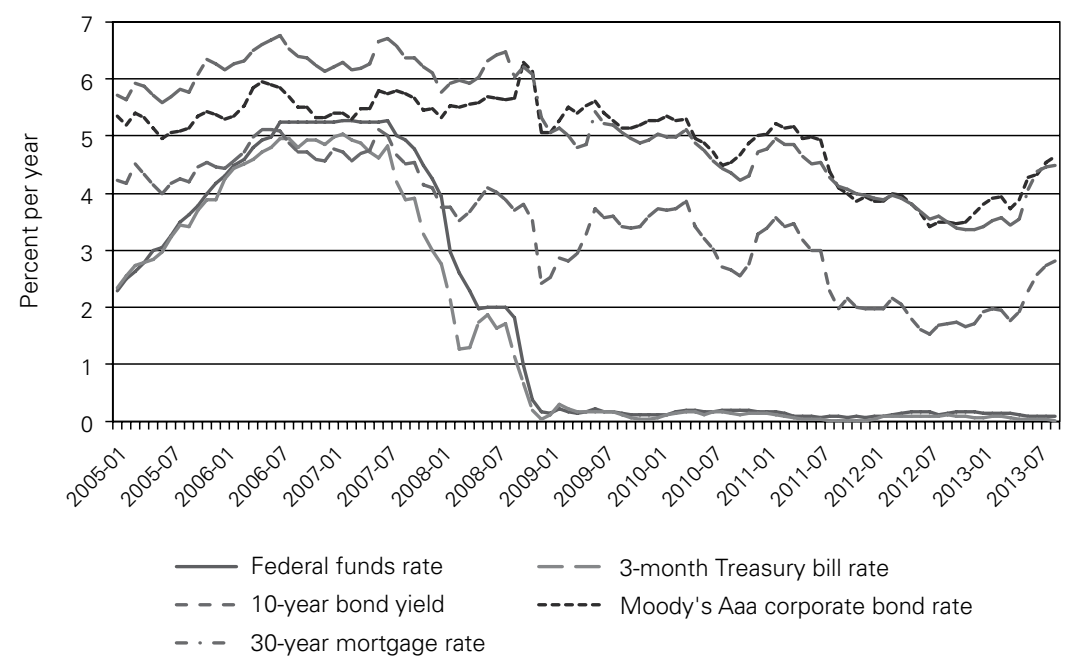

Source: US Federal Reserve Board (FRB), Statistical Release H.15, Selected Interest Rates, http://www.federalreserve.gov/datadownload/default.htm, downloaded October 23, 2013.

\footnotetext{
${ }^{18}$ There are some conceptual differences between the ZLB and a liquidity trap, insofar as the latter refers to a situation in which the demand for money becomes infinitely elastic at a very low (but not necessarily zero) interest rate. Nevertheless, for practical purposes we can use these terms interchangeably to describe the current predicament for US monetary policy.
} 
However, long-term bond rates and lending rates to households and businesses did not decline as much as short-term, money market rates did in response to the Fed's initial actions during the crisis. The yield on 10-year US Treasury securities and the interest rate on 30-year residential mortgages fell by much less than the federal funds rate or 3-month T-bill rate decreased between 2007 and 2009, while the interest rate on Aaa-rated corporate bonds decreased only slightly during that period (see Figure 10). As these long-term and lending rates did not decline as much as the short-term, money market rates, the impact of the Fed's conventional interest rate cuts in stimulating an economic recovery was muted.

Nevertheless, the Fed did not confine itself to conventional policy tools, and instead used aggressive and unprecedented new measures in an effort first to stem the financial crisis and then to encourage a recovery after the recession officially ended. In 2008-9, the Fed cooperated with the US Treasury to rescue key financial players such as AIG, which had issued "credit default swaps" that supposedly insured owners of mortgage-based securities against decreases in their value, but which it could not pay when the entire market for those securities collapsed. The Fed, also in conjunction with the Treasury, bought up large amounts of "toxic assets" to take them off the books of banks or other institutions so that credit market that had "seized up" could be "unfrozen." For example, at one point the Fed purchased a significant portion of all the commercial paper in the US financial sector in order to ensure that business firms could obtain working capital.

Then, when the Fed realized that the recovery was going slowly and various key markets (for example, labor, housing, and credit markets) remained depressed, it decided to take more direct action to lower long-term interest rates and lending rates. The Fed did this by adopting unconventional policies that it refers to as "Large Scale Asset Purchases" (LSAPs), but which are more popularly known as "Quantitative Easing” (QE). Through these policies, the Fed purchased long-term but safe assets (for example, long-term Treasury bonds and agency-guaranteed mortgage securities) in order to diminish the yields on those assets and hence bring down lending rates for households and firms.

After several successive rounds of LSAP/QE policies, it is clear that they had some positive but limited successes. As Figure 10 shows, the yield on 10-year Treasury bonds fell from about $3.7 \%$ in late 2009 and early 2010 to under $2 \%$ in the second half of 2012, before rising back to about 2.7\% in September 2013. Meanwhile, interest rates on Aaa-rated corporate bonds and 30-year fixed rate mortgages diminished from over $5 \%$ in 2009 to about $3.5 \%$ in the second half of 2012, before rising back to about $4.5 \%$ in September 2013. Movements in these rates were also driven by other factors, including changes in long-term inflationary expectations and speculation on the timing of when the Fed would "taper" and/or reverse (unwind) its LSAP programs, as well as by the Fed's actual asset purchases.

A simple measure of the magnitude of the Fed's nonconventional policy interventions is the extraordinary growth of the total assets on its balance sheet since 
the 2008-9 financial crisis ${ }^{19}$. The Fed's total assets increased gradually from about US\$ 725 billion at the beginning of 2003 to slightly over US\$ 900 billion in JulyAugust of 2008, mostly through standard purchases of short-term Treasury bills. Its total assets then jumped to US\$2.2 trillion by December 2008, and grew further to US\$ 3.7 trillion by September 2013. The vast majority of these increases in Fed assets consisted in assets other than the standard short-term Treasury bills. In fact, by October 2013, one of the largest components of these assets was US\$ 1.4 trillion in mortgage-backed securities from the federally guaranteed housing finance agencies known as Fannie Mae, Freddie Mac, and Ginnie Mae.

One consequence of these large-scale asset purchases has been a parallel explosion in the excess (nonrequired) reserves of commercial banks, which rose from negligible levels before the financial crisis (typically US\$ 2 billion or less from 2003 to 2007) to unprecedented levels since then (they shot up to US\$ 1.1 trillion in December 2008, and then doubled to US\$ 2.2 trillion by September 2013) ${ }^{20}$. This huge growth in total bank reserves is a natural outgrowth of the Fed's asset purchases, but the fact that the increased reserves have almost entirely remained as excess reserves can be attributed to the weak growth in bank lending (and hence the relatively small amount of deposit creation) since the financial crisis. Banks are holding these excess reserves in their balance sheets instead of lending them out to potential business or household borrowers, which is another reason why business and household expenditures have remained so weak throughout the recovery.

It is important to recognize that the US economy would be in much more dire straits if the Fed had not taken the various actions that it adopted, even though these actions have not been sufficient to induce a more robust recovery. As we have seen, low interest rates did not stimulate big increases in borrowing and spending by households and businesses in a situation in which income was growing slowly and households continued to be constrained by depressed housing values and large debt burdens. Nevertheless, the Fed's interventions did help to stabilize the financial system in 2008-9, and lower interest rates have enabled indebted households to repair their balance sheets by paying off debt principal more quickly or refinancing previous debt (especially mortgages) with new loans at lower rates. Housing prices have begun to recover, as shown in Figure 7 , and small but positive upticks in housing construction have been recorded in 2012 and the first nine months of 2013. Low interest rates also have held down the value of the US dollar, and may thereby have contributed to the relatively more rapid growth of US exports compared with US imports during the recovery period discussed earlier. Low interest rates on

\footnotetext{
${ }^{19}$ All data in this paragraph are from Federal Reserve Statistical Release H.4.1, Factors Affecting Reserve Balances, release of October 24, 2013, http://www.federalreserve.gov/releases/h41/, and historical data downloaded from http://www.federalreserve.gov/datadownload/.

${ }^{20}$ See Federal Reserve Statistical Release H.3, Aggregate Reserves of Depository Institutions and the Monetary Base, release of October 24, 2013, http://www.federalreserve.gov/releases/h3/, and earlier data downloaded from http://www.federalreserve.gov/datadownload/. The last time that excess reserves were so large, relative to the size of the US economy, was during the Great Depression of the 1930s.
} 
Treasury securities have also enabled the federal government to run historically large budget deficits during the worst of the recession and the beginning of the recovery without incurring significantly greater interest costs on federal government debt, as we will discuss in the next section. But as short-term interest rates have been at or near the ZLB for the past six years and the Fed seems to have reached the limits of its ability to drive down longer-term and lending rates, monetary policy appears to be reaching the limits of its ability to further stimulate the US economy.

\section{Fiscal policy}

The US government adopted four major sets of fiscal policy measures that were designed originally to ameliorate the financial crisis and recession and subsequently to promote an economic recovery. The first two of these were adopted under President George W. Bush in 2008 and the other two under Barack Obama starting in 2009:

- One-time rebates for personal income taxes, spring 2008;

- Troubled Assets Relief Program (TARP), enacted in fall 2008;

- The Obama stimulus package, 2009-2010; and

- Temporary extensions of various tax cuts and unemployment benefits, 2011-2012 .

The stimulative effects of all these policies were both modest and short-lived, and by 2011 - after the Republicans took control of the House of Representatives and engineered a series of artificial fiscal crises - the government adopted a set of severe restrictions on federal spending that have effectively shifted the stance of fiscal policy toward austerity. Starting with the first one, the Bush tax rebates of spring 2008 totaled approximately US\$ 150 billion, which constituted only about $1 \%$ of US GDP at the time, and were not nearly large enough to prevent the already ongoing recession from getting worse; at best these tax cuts may have contributed to the upward blip in GDP growth to a $+2 \%$ annual rate registered in 2008Q2 (GDP growth was negative in the other three quarters of 2008 and the first two quarters of 2009).

In contrast, TARP was not a conventional fiscal stimulus policy, but rather a financial rescue package. It authorized the Treasury to spend up to US\$ 700 billion to purchase assets whose value had collapsed, thereby taking them off the balance sheets of endangered financial institutions, and to make any other asset purchases deemed "necessary to promote financial market stability" by the Secretary of the Treasury in consultation with the Fed Chairman. However, the dramatic way in which then-Secretary of the Treasury Hank Paulson announced the necessity of the TARP legislation immediately after the failure of Lehman Brothers may have contributed to worsening the financial panic at the time (September-October 2008). Also, many of the ultimate uses of TARP funds were not the ones originally empha- 
sized by Paulson. For example, TARP funds were ultimately used more to recapitalize the banks and buy up bank equity, rather than to purchase toxic assets, and they were later used by the Obama administration to finance a US\$ 79.7 billion rescue of the automobile industry. Most importantly, TARP did not impose any conditions on the rescued financial institutions or require any reforms of the practices and incentives that had led to the financial crisis in the first place. Nevertheless, in spite of all these flaws, it probably did contribute (along with the Fed's actions, described above) to preventing a worse collapse of the financial system in 2008-9.

The Obama stimulus plan, officially known as the American Recovery and Reinvestment Act of 2009, was a more conventional expansionary fiscal policy consisting in approximately US $\$ 800$ billion of tax cuts and spending increases that were mostly spread over a two-year period (2009 and 2010). The plan included significant amounts of public investment in energy, infrastructure, and other social needs, but also included various tax cuts and tax incentives - many of which were political compromises designed mainly to win enough votes from Republicans and centrist Democrats for the legislation to pass the Senate (under the "filibuster" rule that requires 60 out of 100 Senators to vote to close debate and allow a final vote on the legislation).

Given the severity of the financial crisis and recession, many economists at the time doubted that this stimulus package was large enough, and there were also concerns about the effectiveness of some of its provisions. For example, it included US $\$ 70$ billion in relief from the Alternative Minimum Tax that probably would have been adopted anyway (similar provisions have been passed every year for the past decade), and hence did not add any additional stimulus to the economy, and it did not focus enough on direct job-creating measures. More than US\$ 50 billion went to state and local governments to prevent layoffs of schoolteachers and other public employees, but this was only temporary and did not lead to increased hiring. In the end, the actual stimulus spending and new tax cuts probably added at most about US\$ 300 billion per year, or only about $2 \%$ of GDP, to the economy during the 2009-10 period, with multiplier effects that were attenuated by the heavy emphasis on tax cuts and budgetary gimmicks. This may have been the biggest stimulus package that Obama could get Congress to approve, and it surely helped to end the recession in the summer of 2009 , but it was not nearly large enough to spark a strong and sustained recovery.

Once most of the Obama stimulus was withdrawn in 2011, fiscal policy essentially reversed gears and began to impose a significant drag on the economy. Part of the Obama stimulus had consisted in aid to state and local governments to support education and other social services; once this aid was terminated, many of those states and localities made significant budget cuts that reduced public sector employment. Many states adopted further fiscal cutbacks and slashed social services on their own, especially after Republicans won a large portion of the state governorships and legislatures in the 2010 midterm elections. The federal government did extend certain tax cuts (both Bush's cuts for personal income taxes and Obama's cuts in payroll taxes for workers) and also extended unemployment ben- 
efits for workers who had lost jobs during 2011 and 2012, but many of these policies were allowed to expire at the end of 2012.

Meanwhile, the Republican majority that took over the House of Representatives in January 2011 used its leverage to create a series of politicallymotivated budget "crises" in order to force draconian cuts in federal government expenditures. Without going into the details, each of the "compromises" adopted to "solve" these crises - for example, to obtain an increase in the debt ceiling in July 2011 - included major reductions in federal government spending. These reductions included (but were not limited to) the so-called "sequester," a set of across-the-board spending reductions that ultimately went into effect in January 2013 and were continued in the deal that ended the government shutdown and raised the debt ceiling again in October 2013. Originally, the idea of the sequester (when it was incorporated into the July 2011 crisis resolution) was to threaten a set of budget cuts so severe that it would induce Republicans and Democrats in Congress to compromise on a deficit-reducing budget plan, but when no compromise resulted the Republicans decided that they would be content to let the sequester go into effect as the economy approached the fiscal cliff at the beginning of 2013. Indeed, President Obama's major victory in the fiscal cliff negotiations in January 2013 was to block an extension of the Bush tax cuts for high-income individuals and families, while extending those cuts for middle- and low-income taxpayers. Although this was a progressive move in terms of tax policy, he essentially gave up on any further fiscal stimulus, allowed the reduction in payroll taxes for workers to expire, and acquiesced in the imposition of the sequester.

The net effect of all these gyrations in US fiscal policy was that real government spending began to decline about three years after the recession began, at a time when the economy had not truly recovered to anything resembling a normal state in terms of growth or employment. Figure 11 compares real government spending (total, including state and local as well as federal) in the first 22 quarters of the present recession-and-recovery compared with the same number of quarters in the previous three recession-recovery periods, using indexes based on 100 in the quarter of the previous cycle peak ${ }^{21}$. Government spending rose moderately (about $6 \%$ ) in the first two years (2008 and 2009) of the current cycle, but no more than it did in two out of the three previous cycles shown (in spite of the greater severity and duration of the 2008-9 recession), and then began falling around the $12^{\text {th }}$ and $13^{\text {th }}$ quarters (around when most of the Obama stimulus expired and the Republicans won back the House of Representatives), so that by the $22^{\text {nd }}$ quarter (2013Q2) it was $1.3 \%$ below its prerecession level in real terms. Although the degree of fiscal stimulus has varied across the last several recessions shown in Figure 11, the absolute reduction in real government spending during the present recovery is unprecedented in modern times, and is undoubtedly a factor in explaining why this recovery has been so sluggish and protracted. Ironically, the biggest spending increases occurred under Republican presi-

\footnotetext{
${ }^{21}$ The comparison shown in Figure 11 was inspired by Krugman (2013), who included only the two most recent recessions.
} 
dents (Reagan and Bush II), mostly as a result of the military buildups for the Cold War and the Iraq War respectively (and these increases occurred in addition to the fiscal stimulus that those presidents provided via tax cuts).

Figure 11: Real US government consumption expenditures and gross investment, first 22 quarters of the last four recessions and recoveries

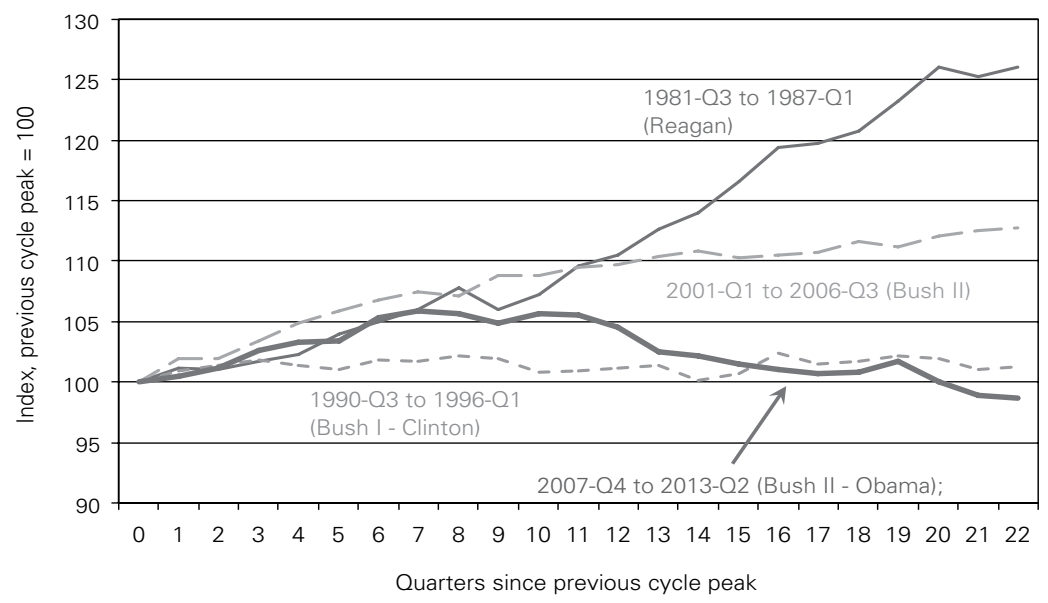

Source: BEA, NIPA Table 1.1.6, data revised 29 August, 2013, www.bea.gov, and author's calculations.

In terms of the politics involved, it is important to note that many Democrats have often been willing partners in the drive to impose fiscal austerity, even if they would prefer to achieve this more via tax increases rather than spending cuts. Many Democrats, including President Obama, have accepted the logic that reducing the budget deficit should be a major policy priority, at least for the long run if not in the short run, and they are clearly willing to make compromises that (against all sensible economics) would target deficit reduction in the short run during a still-fragile recovery. In so doing, they have given in to the ideologically driven agenda of the Republicans, led by Tea Party fanatics and their billionaire funders, to shrink the size of the public sector. Yet, the increase in the budget deficit was a symptom of the crisis, recession, and slow recovery, not a cause of those events, and the effort to reduce the deficit prematurely during the recovery has only slowed the recovery further and prolonged the depressed levels of income and employment noted earlier.

Contrary to what deficit hawks from both parties have claimed, the US is not in any kind of fiscal crisis ${ }^{22}$. On a fiscal year basis ${ }^{23}$, from the year before the recession (2007) to the year of the recession trough (2009), the US federal budget defi-

\footnotetext{
${ }^{22}$ For broader perspectives on US fiscal policy, see Baker (2013) and Cynamon and Fazzari (2013a).

${ }^{23}$ The fiscal year for the US federal government runs from October 1 to September 30, and is numbered for the calendar year in which it ends.
} 
cit increased from $2.5 \%$ to $10.2 \%$ of GDP (see Table 3), mainly as a result of reduced tax revenue due to the recession as well as the temporary stimulus spending and automatic stabilizers. At the same time, the federal debt held by the public (i.e., excluding the part of the debt held by the Federal Reserve and other government entities) rose from $34.6 \%$ to $52.5 \%$ of GDP, and it increased further to a projected (and still very manageable) $72.9 \%$ at the end of fiscal $2013^{24}$. Although the debtto-GDP ratio appears to be stabilizing in the $70 \%$ range, even much higher ratios would not necessarily imply any adverse consequences for growth, as shown by Herndon et al. (2013). Debt ratios anywhere close to present US levels are clearly sustainable, especially in light of the fact that that the US - unlike most other countries - can borrow in its own currency.

Table 3: US federal government fiscal indicators, selected fiscal years, in percent

\begin{tabular}{lcccc}
\hline & Pre-crisis & Recession trough & \multicolumn{2}{c}{ Last two years } \\
\hline & 2007 & 2009 & 2012 & 2013 \\
\hline Federal net lending or borrowing/GDP & -2.5 & -10.2 & -7.5 & -4.3 \\
Federal debt held by public/GDP & 34.6 & 52.5 & 69.0 & 72.9 \\
Federal net interest payments/GDP & 2.8 & 2.5 & 2.6 & 2.6 \\
\hline
\end{tabular}

Sources: BEA, National Income and Product Accounts, Table 1.1.5, www.bea.gov; US Council of Economic Advisers, Economic Indicators, August 2013, http://www.gpo.gov/fdsys/browse/collection. action?collectionCode=ECONI; and author's calculations.

Notes: All ratios are expressed as percentages, for fiscal years ending September 30 of the year shown; federal debt is measured as of September 30. Data for 2013 are estimated.

Meanwhile, as a result of the low interest rate policy of the Fed discussed earlier, there was no increase in the federal net interest payments as a percentage of GDP in spite of the increase in debt. On the contrary, these payments actually declined slightly from $2.8 \%$ of GDP in fiscal 2007 to $2.6 \%$ in fiscal 2013 (see Table 3 ). Furthermore, fiscal austerity combined with increases in tax revenue due to the recovery led to a decrease in the federal budget deficit to only $4.3 \%$ of GDP by fiscal 2013. None of the conventional arguments against budget deficits apply in this situation, where interest rates are so low that there is no crowding out of investment, the dollar is so low that net exports are being crowded in instead of out, there are massive amounts of unemployed or underemployed resources available to the private sector, and government debt has been contained to easily sustainable levels ${ }^{25}$.

\footnotetext{
${ }^{24}$ All data for fiscal 2013 are estimated.

${ }^{25}$ Many of the claims that US fiscal policy is unsustainable stem from alarming projections of long-term deficits and debt increases due to growing future government obligations for the major "entitlement" programs for senior citizens, Social Security and Medicare, several decades into the future (see, for example, US Congressional Budget Office, 2013). However, these projections tend to be based on
} 


\section{CONCLUSIONS ON MACRO POLICIES}

As the US recovery drags into its fifth year, with so many economic indicators (including employment, housing, and investment) still below their peak levels from before the recession (i.e., six years earlier), it is clear that the US government is now pursuing a dysfunctional and counterproductive policy approach. Monetary policy has remained highly expansionary, but in a situation in which it currently has little efficacy, while fiscal stimulus has been prematurely abandoned. Of course, no amount of demand-side policy stimulus, fiscal or monetary, could solve all the problems of the US economy, particularly those attributable to the structural changes and increasing inequality noted earlier. But the adoption of fiscal austerity, based on a combination an ideological drive to shrink the size of the public sector (on the part of right-wing Republicans) and a fixation on reducing the budget deficit (by politicians of both major parties), is depressing the US economy even further and endangering the recovery without serving any useful economic purpose.

The US needs a return to a stimulative fiscal stance, following Obama's original idea of investing in public infrastructure and priority areas of social policy (for example, education, energy, and the environment), coupled with a greater emphasis on immediate job creation ${ }^{26}$. Such an approach would have the double benefit of accelerating the recovery in the short run and laying the groundwork for more sustainable growth in the long run. Indeed, recent research recognizes that supplyside factors are endogenous in the long run, and as a result the currently depressed level of investment is endangering long-run growth as well as the short-run recovery. Although their evidence for adverse feedbacks to long-term productive capacity is stronger for capital accumulation, Reifschneider et al. (2013, p. 29) note that such effects may also arise from the persistence of slack labor markets:

[...] the unusual length and severity of the Great Recession, together with the fact that unemployment has been atypically concentrated among the long-term unemployed, seem likely erode the skills and workforce attachment of some unemployed persons. Historically, there has been much less evidence of hysteresis in US labor markets than in European ones, but, as we noted earlier, the severity and unprecedented characteristics of the recent recession suggest the possibility that the United States will not

\footnotetext{
pessimistic assumptions about unknowable conditions (e.g., productivity) in the distant future. The genuine problems of Social Security finance are easily solvable through relatively minor changes in the program, while the problems with Medicare result largely from the inability of the US to keep its health care costs under control as its population ages. In any case, the present cutbacks in so-called "discretionary" programs do not contribute to addressing these long-term issues, and the best way to make both Social Security and Medicare affordable and the US debt sustainable in the long run would be to promote more rapid growth and higher employment levels.

${ }^{26}$ For estimates of the degree to which increased government spending on public infrastructure and R\&D would improve the growth prospects for the US economy over the next several years, see Papadimitriou et al. (2013).
} 
remain free of hysteresis-type effects this time. In principle, hysteresis in labor markets could cause a period of slack demand to have long-lasting adverse implications for the productive capacity of the economy.

Reifschneider et al. focus on monetary policy rather than fiscal policy, and do not address the direct consequences of fiscal austerity for long-run growth. However, by the same logic that they apply to reductions in private capital accumulation and labor force participation, cutbacks in public investment in infrastructure, reductions in education and R\&D spending, and other austerity measures that inhibit the formation of public, human, or intellectual capital are also likely to diminish the economy's productive capacity and endanger its future growth. Thus, the fiscal austerity policies that are motivated by a supposed concern for the welfare of future generations are actually contributing to worsening the economic prospects of those future generations rather than improving them, through both their direct effects in slashing public investment and their indirect effects in discouraging private capital formation and job creation.

\section{LESSONS AND CONCLUSIONS}

The US economy is suffering from two related problems of slow growth: first, a sluggish short-term recovery from the 2008-9 recession and the financial crisis that provoked it; and second, a secular growth slowdown that dates back to about 2000-1. As we have seen, these twin problems have emerged from a combination of the increasing inequality in the distribution of income, the collapse of a model of growth founded upon rising household debt, long-term structural changes in the composition of US industries, and an inadequate macro policy response including counterproductive fiscal austerity. Among the many symptoms of this economic stagnation, probably the most significant in human terms is the enormous jobs crisis: employment is still below its 2007-8 peak more than five years after the recession started, and over the entire period from 2000-13 there was very little job growth overall, especially compared to the rapid job creation in the preceding decades.

This US experience demonstrates three important lessons that validate three key propositions in economic theory:

- The paradox of thrift: Output in a market economy is normally constrained not by the supply of saving, but rather by the level of aggregate demand including consumption, investment, government purchases, and net exports. During the recession and recovery, US households have effectively increased their savings as they have sought to pay down their debts and restore their balance sheets, which of course is individually rational given the collapse of household asset values (especially house prices) and uncertain employment prospects. Meanwhile, US corporations have increased their net savings by amassing large amounts of profits in excess of their investment expenditures, which is also individually rational given the weak growth of demand for their 
products. However, these increases in saving rates have only led to continued stagnation as consumer demand, housing construction, and business investment have not increased enough to stimulate a stronger recovery. This validates the paradox of thrift argument made long ago by Keynes (1936).

- Wage-led demand: Kalecki (1954 [1968]) and Steindl (1952 [1976]) suggested that a redistribution of income from wages to profits would cause economic stagnation by depressing aggregate demand, and later developments of their theoretical approach (surveyed by Blecker, 2002a) showed how aggregate demand could be wage-led if the benefits of higher wages for consumer demand outweigh any possible negative effects on investment or net exports. Theoretically, it is also possible for the latter effects to dominate and for an economy to be profit-led (Blecker, 1989; Marglin \& Bhaduri, 1990). Nevertheless, the evidence cited here - especially the association of a falling wage share and increasing inequality with slower growth of output and employment - strongly supports the findings of some recent econometric studies (e.g., Onaran et al., 2011) showing that the US economy remains wage-led. Importantly, our analysis of the US case suggests that business investment is ultimately more responsive to demand growth (the "accelerator effect") than to profitability, implying that a redistribution toward profits in the absence of an increase in consumer and other demand will fail to stimulate investment.

- Fiscal austerity is not expansionary: The myth that fiscal austerity is expansionary should have been laid to rest by many past experiences, from the Great Depression and World War II in the 1930s and 1940s to the crises in various eurozone countries (Greece, Spain, Ireland, and others) since 2010. Nevertheless, the current US situation is another case in point. The US recession ended and a recovery began in 2009, when the government adopted a mild fiscal stimulus in combination with massive financial rescues and monetary expansion. After US fiscal policy moved toward austerity in late 2010 and early 2011, an already weak recovery began to falter. Under the still-depressed circumstances of 2013, there is no conceivable way in which government deficits could be crowding out private sector activity, either through financial markets (where interest rates remain historically low) or in terms of resources (given massive continued unemployment and a major reduction in labor force participation). On the contrary, the withdrawal of public sector spending is simply reducing aggregate demand and employment below what they would otherwise be, while starving public investment in key areas for future growth such as infrastructure, education, and research. Unfortunately, the US public sector is under attack precisely at a time when the US government needs to become much more of a developmentalist state, in the sense of Bresser-Pereira (2010), in order to address the structural and distributional problems that are inhibiting both the short-term recovery and the long-term growth of the US economy. 
For the rest of the world, especially emerging market nations like Brazil, the stagnation of the US economy poses significant challenges. Considering also the weakness of the European economies, the outlook for demand growth in the largest markets of the developed world is presently quite bleak. In contrast, most of the Asian economies have continued to grow relatively fast in spite of these lingering troubles in the West. Indeed, the demand of China and other major exporters of manufactured goods has been a chief source of the high prices of primary commodities that have benefited resource-exporting nations, both before and after the crisis. Even Japan, whose growth had faltered since it experienced its own financial crisis during the 1990s, is now finding a path back to economic growth through expansionary macro policies (which, as we saw earlier, have reduced its current account surplus). But the US and EU generally have been better customers for the manufactured exports of developing nations over the past few decades, and these are the economies that are likely to be the most slow-growing for the foreseeable future - not to mention, each of them has its own "periphery" (Mexico in North America; Eastern Europe in the EU) from which it sources a large proportion of its manufactured imports.

In this context, Brazil and other emerging market nations will experience heightened competitive pressures due to another key theoretical proposition:

- The fallacy of composition in export-led growth: As more and more developing countries pursue paths of export-led growth, particularly when focused on manufactured goods, they face an adding-up constraint insofar as they are all trying to penetrate the same limited markets in the industrialized countries at the same time (see Blecker, 2002c; Blecker \& Razmi, 2008, 2010). A few countries can succeed in such export-led growth when there is limited competition, but as more and more countries enter the fray, the competition grows more intense and some can succeed only at the expense of others ${ }^{27}$. This competition can be relieved to some extent if some countries move "up the industrial ladder" to more technologically sophisticated goods, leaving more labor-intensive products (such as apparel and footwear) for the lower-wage countries, but even on the higher rungs of the ladder the competition in more technologically advanced products is now growing more intense. When the markets in most of the leading industrialized nations are growing slowly, as they currently are, this problem is all the more acute.

The fallacy of composition is not inevitable, however; it only arises if the exporting nations target a limited set of markets in certain other nations and fail to provide reciprocal demand for each others' expanding exports. If, on the contrary, the exporting nations also provide growing markets for each others' products in a mutual and balanced way, then the fallacy of composition can be overcome, and the

\footnotetext{
${ }^{27}$ The way that Chinese exports displaced Mexican exports in the US market during the early 2000s is a recent case in point. See, for example, Gallagher et al. (2008), Feenstra and Kee (2009), and Hanson and Robertson (2009).
} 
benefits of export-led growth (for example, in terms of scale economies and technological learning) can be shared by all. Indeed, one of the reasons why the South and East Asian countries have done relatively better in recent decades is the rise in their intra-regional trade, which has at least partly mitigated the effects of the growth slowdown in western markets. Nevertheless, even China is now facing the need to restructure its economy and focus more on internal consumer demand as its main export markets are depressed while its wages are rising and its currency is appreciating (see Pettis, 2013). In general, the more that the emerging nations are able to expand their own internal markets as well as their reciprocal trade with each other, the more they will be able to escape from the fallacy of composition.

Thus, as Brazil seeks to increase its exports of manufactures, it will have to determine how to navigate the perilous waters of a global economy in which some major markets are likely to remain severely constrained for the foreseeable future. Unless Brazil is able to substantially increase its share of the slow-growing markets in North America and Western Europe, it will have to expand its exports of manufactures to Asia, other Latin American nations, and emerging nations in other regions in which markets are growing more rapidly than in the US or EU. To facilitate such expansion, it is vital that the emerging market countries as a group increase their reciprocal demand for each other's manufactured products, and not continue the presently one-sided pattern of exchanging manufactures from some countries for primary commodities from others ${ }^{28}$. In this environment, Brazil will need to find a way in which to enter global value chains that brings significant value added and positive developmental gains into its economy, while at the same time expanding its own internal market so that its industries do not have to depend too heavily on uncertain conditions in foreign export markets.

\section{REFERENCES}

AUTOR, D. H.; DORN D.; HANSON, G. H. (2013). The China syndrome: local labor market effects of import competition in the United States, American Economic Review, 103 (6), pp. 2121-68.

BAKER, D. (2013). Fiscal policy: the recent record and lessons for the future, in CYNAMON, B. Z.; FAZZARI, S. M.; SETTERFIELD, M. (eds.), After the Great Recession: The Struggle for Economic Recovery and Growth, Cambridge: Cambridge University Press.

BARBOSA FILHO, N. H.; TAYOR, L. (2006). Distributive and demand cycles in the US economy: a structuralist Goodwin model, Metroeconomica, 57 (3), pp. 389-411.

BASU, D.; FOLEY D. K. (2013). Dynamics of output and employment in the US economy, Cambridge Journal of Economics, 37, pp. 1077-1106.

\footnotetext{
${ }^{28}$ As Brazilians know all too well, export-led growth that is focused mainly on resource-based exports can be at best a mixed blessing and at worst a curse, as it typically leads to the Dutch Disease of an overvalued currency that inhibits the competitiveness of manufacturing industries. See, for example, Bresser-Pereira (2010) and Bresser-Pereira and Marconi (2008), and discussion throughout the present volume.
} 
BLECKER, R. A. (1989). International competition, income distribution and economic growth, Cambridge Journal of Economics, 13 (3), pp. 395-412.

BLECKER, R. A. (2002a). Distribution, demand, and growth in neo-Kaleckian macro models, in SETTERFIELD, M. (ed.), The Economics of Demand-Led Growth: Challenging the Supply-Side Vision of the Long Run, Cheltenham, UK: Edward Elgar.

BLECKER, R. A. (2002b). International capital mobility, macroeconomic imbalances, and the risk of global contraction, in EATWELL, J.; TAYLOR, L. (eds.), International Capital Markets: Systems in Transition, New York: Oxford University Press.

BLECKER, R. A. (2002c). The balance-of-payments-constrained growth model and the limits to export-led growth," in DAVIDSON, P. (ed.), A Post Keynesian Perspective on Twenty-First Century Economic Problems, Cheltenham, UK: Edward Elgar, 2002.

BLECKER, R. A. (2011). Open economy models of growth and distribution," in HEIN, E.; STOCKHAMMER, E. (eds.), A Modern Guide to Keynesian Macroeconomics and Economic Policies, Cheltenham, UK: Edward Elgar.

BLECKER, R. A. (2013). Global imbalances and the U.S. trade deficit, in CYNAMON, B. Z.; FAZZARI, S. M.; SETTERFIELD, M. (eds.), After the Great Recession: The Struggle for Economic Recovery and Growth, Cambridge: Cambridge University Press.

BLECKER, R. A.; RAZMI, A. (2008). The fallacy of composition and contractionary devaluations: output effects of real exchange rate shocks in semi-industrialised countries, Cambridge Journal of Economics, 32 (1), pp. 83-109.

BLECKER, R. A.; RAZMI, A. (2010). Export-led growth, real exchange rates, and the fallacy of composition, in SETTERFIELD, M. (ed.), The Handbook of Alternative Theories of Economic Growth, Cheltenham, UK: Edward Elgar.

BRESSER PEREIRA, L. C. (2010). Globalization and Competition: Why Some Emergent Countries Succeed while Others Fall Behind, Cambridge: Cambridge University Press.

BRESSER PEREIRA, L. C.; MARCONI, N. (2008). Existe doença holandesa no Brasil?, in Bresser Pereira, L. C. (org.), Doença Holandesa e Indústria, Rio de Janeiro: Editora da Fundação Getulio Vargas.

CARVALHO, L. B. (2013). "Current Account Rebalancing Since the Crisis”, INET Institute Blog, http://ineteconomics.org/blog/institute/current-account-rebalancing-crisis.

CHIRINKO, R. S. (1993). Business fixed investment spending: Modeling strategies, empirical results, and policy implications, Journal of Economic Literature, 31 (4), pp. 1875-1911.

CHIRINKO, R. S.; FAZZARI, S. M.; MEYER, A. P. (1999). How responsive is business capital formation to its user cost? An exploration with micro data, Journal of Public Economics, 74 (1), pp. 53-80.

CYNAMON, B. Z.; FAZZARI, M. (2013a). No need to panic about U.S. government deficits, in CYNAMON, B. Z.; FAZZARI, S. M.; SETTERFIELD, M. (eds.), After the Great Recession: The Struggle for Economic Recovery and Growth. Cambridge: Cambridge University Press.

CYNAMON, B. Z.; FAZZARI, M. (2013b). The end of the consumer age, in CYNAMON, B. Z.; FAZZARI, S. M.; SETTERFIELD, M. (eds.), After the Great Recession: The Struggle for Economic Recovery and Growth. New York: Cambridge University Press.

FEENSTRA, R. C.; KEE, H. L. (2009). Trade liberalization and export variety: A comparison of Mexico and China," in LEDERMAN, D.; OLARREAGA, M.; PERRY, G. E. (eds.), China's and India's Challenge to Latin America: Opportunity or Threat? Washington: World Bank.

GALLAGHER, K. P.; MORENO-BRID, J. C.; PORZECANSKI, R. (2008). The dynamism of Mexican exports: Lost in (Chinese) translation? World Development, 36 (8), pp. 1365-80.

HANSON, G. H.; ROBERTSON, R. (2009). China and the recent evolution of Latin America's manufacturing exports, in LEDERMAN, D.; OLARREAGA, M.; PERRY, G. E. (eds.), China's and India's Challenge to Latin America: Opportunity or Threat? Washington: World Bank.

HERNDON, T.; ASH, M.; POLLIN, R. (2013). "Does High Public Debt Consistently Stifle Economic Growth? A Critique of Reinhart and Rogoff”, Working Paper No. 322, Political Economy Research Institute, University of Massachusetts, Amherst, April. 
KALECKI, M. (1954). Theory of Economic Dynamics, London: Allen and Unwin, reprinted New York: Monthly Review Press, 1968.

KEYNES, J. M. (1936). The General Theory of Interest, Employment and Money, London: Macmillan. KRUGMAN, P. (2011). “The lesser depression”, New York Times, July 21.

KRUGMAN, P. (2012). End This Depression Now! New York: Norton.

KRUGMAN, P. (2013). "What Janet Yellen — and everyone else — got wrong”, New York Times, blog post, August 8, http://krugman.blogs.nytimes.com/2013/08/08/what-janet-yellen-and-everyone-else-got-wrong/?.

MARGLIN, S. A.; BHADURI, A. (1990). Profit squeeze and Keynesian theory, in MARGLIN, S. A.; SCHOR, J. B. (eds.), The Golden Age of Capitalism, Oxford: Oxford University Press.

McKINSEY GLOBAL INSTITUTE (2012). Manufacturing the Future: The Next Era of Global Growth and Innovation, Washington: McKinsey \& Co., November.

MILBERG, W.; WINKLER, D. (2013). Outsourcing Economics: Global Value Chains in Capitalist Development. Cambridge, UK: Cambridge University Press.

MINSKY, H. P. (1986). Stabilizing an Unstable Economy, New Haven: Yale University Press.

MISHEL, L. (2012). "The Wedges Between Productivity and Median Compensation Growth", Issue Brief No. 330, Economic Policy Institute, Washington, April.

MISHEL, L.; BIVENS, J.; GOULD, E.; SHIERHOLZ, H. (2012). State of Working America, $12^{\text {th }}$ edition. Ithaca: Cornell University Press for the Economic Policy Institute.

OBAMA, B. (2013). "Remarks by the President at SelectUSA Investment Summit”, Washington, DC, October 31, http://www.whitehouse.gov/the-press-office/2013/10/31/remarks-president-selectusa-investment-summit.

OLNEY, M. L.; PACITTI, A. (2013). “Goods, Services, and the Pace of Economic Recovery”, University of California, Berkeley, and Siena College, March, http://emlab.berkeley.edu/ olney/services. pdf.

ONARAN, Ö.; STOCKHAMMER, E.; GRAFL, L. (2011). Financialisation, income distribution and aggregate demand in the USA, Cambridge Journal of Economics, 35, pp. 637-61.

PALLEY, T. I. (2013). America's exhausted paradigm: Macroeconomic causes of the financial crisis and Great Recession, in CYNAMON, B. Z.; FAZZARI, S. M.; SETTERFIELD, M. (eds.), After the Great Recession: The Struggle for Economic Recovery and Growth. Cambridge: Cambridge University Press.

PAPADIMITRIOU, D. B.; HANNSGEN, G. H.; NIKIFOROS, M.; ZEZZA, G. (2013). "Rescuing the Recovery: Prospects and Policies for the United States", Levy Economics Institute of Bard College, Strategic Analysis, October.

PETTIS, M. (2013). Avoiding the Fall: China's Economic Restructuring, Washington: Carnegie Endowment for International Peace.

POLLIN, R. (2003). Contours of Descent: U.S. Economic Fractures and the Landscape of Global Austerity, London: Verso.

REIFSCHNEIDER, D.; WASCHER, W. L.; WILCOX, D. (2013). “Aggregate Supply in the United States: Recent Developments and Implications for the Conduct of Monetary Policy”, Paper presented at the $14^{\text {th }}$ Jacques Polak Annual Research Conference, International Monetary Fund, Washington, November.

ROUBINI, N.; MIHM, S. (2011). Crisis Economics: A Crash Course in the Future of Finance, updated with a new afterword, New York: Penguin.

SAEZ, E. (2013). "Striking it Richer: The Evolution of Top Incomes in the United States, Updated with 2012 preliminary estimates”, University of California, Berkeley, September, http://elsa.berkeley. edu/ saez/saez-UStopincomes-2012.pdf.

SAMUELSON, P. A. (1939). A synthesis of the principle of acceleration and the multiplier, Journal of Political Economy, 47, pp. 786-97.

SCOTT, R. E. (2008). "The burden of outsourcing: U.S. non-oil trade deficit costs more than 5 million jobs”, Briefing Paper No. 222, Washington, DC: Economic Policy Institute.

SCOTT, R. E. (2011). "The China toll: Growing U.S. trade deficit with China cost more than 2.7 
million jobs between 2001 and 2011, with job losses in every state”, Briefing Paper No. 345, Washington, DC: Economic Policy Institute.

SETTERFIELD, M. (2013). Wages, demand, and U.S. macroeconomic travails, in CYNAMON, B. Z.; FAZZARI, S. M.; SETTERFIELD, M. (eds.), After the Great Recession: The Struggle for Economic Recovery and Growth. Cambridge: Cambridge University Press.

SHILlER, R. J. (2008). The Subprime Solution: How Today's Global Financial Crisis Happened, and What to Do about It, Princeton: Princeton University Press.

STEINDL, J. (1952). Maturity and Stagnation in American Capitalism. Oxford: Blackwell, reprinted New York: Monthly Review Press, 1976.

STIGLITZ, J. E.; WEISS, A. (1981). Credit rationing in markets with imperfect information, American Economic Review, 71 (3), pp. 393-410.

US CONGRESSIONAL BUDGET OFFICE (2013). The 2013 Long-Term Budget Outlook. Washington: US Congress, September.

WISMAN, J. D. (2013). Wage stagnation, rising inequality and the financial crisis of 2008 Cambridge Journal of Economics, 37 (4), pp. 921-45. 